\title{
SOCIABILIDADES NUMA PEQUENA CIDADE PORTUÁRIA DO SUDOESTE AFRICANO (1884-1914)
}

\author{
Sílvio Marcus de Souza Correa \\ Universidade Federal de Santa Catarina \\ silvio.correa@ufsc.br
}

\begin{abstract}
Resumo
Algumas formas de sociabilidade na Alemanha do II Reich tiveram suas similares nas colônias alemãs do Ultramar. Durante o colonialismo alemão, a vida associativa garantiu a reprodução das sociabilidades em cidades portuárias como Swakopmund e Dar es Salaam. A Baía de Lüderitz foi o primeiro porto da colônia alemã do sudoeste africano (atual Namíbia) e, por conseguinte, um dos primeiros lugares na África de emulação das sociabilidades urbanas do Segundo Império Alemão (1871-1918). A partir da análise de jornais da imprensa colonial em língua alemã, o presente artigo trata das sociabilidades numa pequena cidade portuária do sudoeste africano desde a sua incorporação ao império alemão em 1884 até a ocupação de tropas sul-africanas em 1914.
\end{abstract}

\section{Palavras-chave}

Sociabilidades, Colonialismo alemão, Namíbia

\section{Abstract}

Some forms of sociability in Germany during the Second Empire were similar in the German colonies from overseas. The associative life assured the reproduction of sociability in different African localities under German colonial rule, mainly in seaport cities like Swakopmund and Dar es Salaam. Lüderitz's Bay was the first seaport of German South-West Africa (now Namibia) and therefore one of the first places in Africa to emulation of urban sociability of the German Second Empire (1871-1918). From the analysis of German colonial newspapers, this article will show how was formed the sociability in a South-West African Seaport since its incorporation into the German Empire (1884) until the South-African occupation (1914).

\section{Keywords}

Sociability, German colonialism, Namibia 


\section{Introdução}

Desde os meados do século XVIII, os espaços públicos nas cidades europeias aumentaram e se diversificaram (AGULHON, 2009; LILTI, 2005; KALE, 1994). Isso não ocorreu sem a emergência de novas formas de sociabilidades urbanas. ${ }^{1}$ Também não tardou para essas ultrapassarem as fronteiras da Europa à época do imperialismo. Nos confins dos impérios coloniais, as cidades portuárias favoreceram a reprodução e a emulação de algumas formas de sociabilidade. Contudo, elas tiveram suas particularidades em contexto colonial.

A sociabilidade pode se traduzir por uma "aptidão para viver intensamente relações públicas". Ela depende das formas de interação social entre os indivíduos. Nesse sentido, a sociabilidade pode ser um elemento de coesão para aqueles em condição social similar. Nisso, ela pode se aproximar da polidez que funciona mais como um elemento de equilíbrio entre aqueles de condições sociais distintas. Tal isonomia no tratamento tem a ver com a própria ideia burguesa de igualdade. Desse modo, as práticas de sociabilidade podem esmaecer a distância social no seio de uma comunidade, oferecendo uma imagem mais homogênea de si mesma.

As formas modernas de sociabilidade têm correlação com a ordem burguesa e, por conseguinte, com uma nova urbanidade. A propósito, a civilidade estava se tornando um direito democrático na Europa do final do século XIX, algo que todos podiam, ou pelo menos deveriam, compartilhar. Chegou-se a cogitar uma "cortesia igualitária", aplicada a todos sem distinção de posição social ou fortuna (WEBER, 1988, p. 293).

Em geral, as práticas de sociabilidade ocorrem de forma regular; porém, com diferentes frequências. Há também ocasiões esporádicas, mas são as regulares e as de maior frequência (diárias ou semanais) que garantem aos indivíduos a prática intensa de uma vida social.

As formas de praticar uma vida social e os diferentes espaços para isso podem revelar aspectos de uma ordem política vigente, bem como de estruturas e dinâmicas culturais existentes em um determinado período. Além disso, a sociabilidade tem uma dimensão geográfica e pela qual se expressa um "temperamento regional"

\footnotetext{
${ }^{1}$ Alguns estudos apontam nuances conceituais sobre a sociabilidade em diferentes países da Europa (FRANÇOIS, 1987; NATHAUS, 2009). Na Alemanha, por exemplo, o equivalente à sociabilidade seria a palavra "Geselligkeit". Sociabilidade pode haver ainda correlação com o sentido associativo de "Vereinswesen" (IMHOF, 1982; DANN, 1984; MEYER, 2006). Na Inglaterra, utiliza-se mais o conceito de "Conviviability". Tal conceito remete a uma forma de interação social já apontada pelo sociólogo alemão Georg Simmel como "o laço de reciprocidade que paira de certa forma livremente entre os indivíduos". Na sociologia, o aporte interacionista muito contribuiu para a compreensão da sociabilidade no espaço urbano (FORSÉ, 1980). Na historiografia, destacam-se alguns trabalhos sobre a sociabilidade, sobretudo na França (AGULHON, 1966; GUTTON, 1979; CHALINE, 1995; FUMAROLI, 2003; LILTI, 2005).
}

URBANA, V.4, no5, dez.2012 - Dossiê: Cidades e Sociabilidades - CIEC/UNICAMP 
(AGULHON, 1966). Por isso, faz-se necessário delimitar previamente o campo de análise a partir da identificação das instituições locais ou formas específicas de sociabilidade numa região. Nesse sentido, as associações locais se tornam um critério possível para o estudo da sociabilidade. Apesar do seu caráter restritivo ou parcial, tal procedimento metodológico oferece a vantagem de estudar a sociabilidade por meio de uma história das associações.

Pode-se supor sem receio de maiores objeções que uma evolução progressiva da sociabilidade consiste na aparição de associações voluntárias (AGULHON, 2009, p. 39). Por isso, as associações (esportivas, artísticas, culturais, etc.) parecem ser um bom indicador da sociabilidade de uma coletividade. Com base em matérias e anúncios de um conjunto de jornais em língua alemã, ver-se-á a seguir a manifestação de formas de sociabilidade numa pequena cidade portuária do sudoeste africano à época do colonialismo alemão. ${ }^{2}$

\section{O balbuciar das sociabilidades na "África alemã"}

Os primórdios das sociabilidades na África sob domínio colonial alemão remetem aos casuais encontros de oficiais militares, de soldados, de funcionários do império, de comerciantes e de colonos alemães nos navios a vapor da companhia Woermann até a frequentação nos salões dos primeiros hotéis próximos aos portos marítimos. Houve ainda a participação dessa gente nas primeiras comemorações cívicas ou festividades religiosas em localidades onde os alemães hastearam a bandeira do II Reich.

Mas não tardou para o surgimento das primeiras associações que passaram a organizar reuniões, encontros e várias atividades para cumprir com seus objetivos recreativos ou esportivos e sociais. No final do século XIX, a vida associativa já fazia parte da realidade social em vários locais sob domínio colonial alemão, sobretudo na então colônia do sudoeste africano, onde a população branca teve maior peso demográfico em relação às demais colônias alemãs na África (WESSELING, 2004, p. 364).

Cabe lembrar que a vida social é mais rica, mais intensa e mais diversificada

\footnotetext{
${ }^{2}$ Os jornais Windhoeker Anzeiger (WA), Deutsch-Südwestafrikanische Zeitung (DSWAZ) e Lüderitzbuchter Zeitung (LZ), respectivamente de Windhuk, Swakopmund e Baía de Lüderitz, formam a base empírica desta pesquisa sobre sociabilidade na colônia alemã do sudoeste africano (1884-1914). Como o jornal local da Baía de Lüderitz foi criado somente em 1909, há uma lacuna sobre a vida social dos primeiros 25 anos da pequena cidade portuária do sudoeste africano. Para tratar da vida social na Baía de Lüderitz durante esse período inicial, os jornais de Windhuk e Swakopmund foram fontes imprescindíveis, sobretudo a rubrica "Do Protetorado" (Aus dem Schutzgebiet), relativa às notícias das demais localidades da colônia alemã do sudoeste africano. As rubricas "Nossas outras colônias" (Unsere anderen Kolonien) e "das outras colônias" (Aus den anderen Kolonien) do jornal Deutsch-Ostafrikanische Zeitung (DOAZ), de Dar es Salaam, serviram, igualmente, para coligir informações sobre a sociabilidade na "África alemã".
} 
em cidades ou povoados do que em fazendas isoladas (AGULHON, 2009, p. 35). Também costumes e ideias estiveram mais suscetíveis às influências metropolitanas nas cidades portuárias como Swakopmund e a Baía de Lüderitz do que em sítios interioranos do sudoeste africano.

Se as cidades portuárias da colônia alemã do sudoeste africano tinham uma vida social mais intensa e um maior número de associações (esportivas, recreativas, artísticas e beneficentes) do que algumas localidades interioranas, os espaços de sociabilidade não variavam muito. A vida social se desenvolveu em grande parte nos salões dos restaurantes ou hotéis, onde as primeiras associações realizavam suas reuniões semanais ou mensais. Em Swakopmund, a reinauguração do restaurante de J. Leuffgen destacava a sua localização à beira-mar e próxima aos moles, bem como o fato de ser o estabelecimento o preferido pelas associações locais de Ginástica e de Combatentes (WA, 03.08.1899, p. 4). Em 1898, na pequena Windhuk, o restaurante de John Ludwig oferecia aos seus clientes atrativos como boliche, bilhar e piano. Também havia boliche no restaurante e hotel Deutsches Haus (WA, 12.10.1898, p. 3).

Na África Oriental Alemã (atual Tanzânia), o hotel Deutscher Kaiser era o mais antigo da praça de Dar es Salaam e equipado também com boliche, bilhar francês e piano (DOAZ, 26.02.1899, p. 7). Havia ainda o hotel "Príncipe Bismarck", onde a banda municipal fazia concerto (DOAZ, 15.07.1899, p. 3). Também um concerto natalino com a banda marcial do navio imperial "Herzog" se realizou no hotel de propriedade da alemã Martha Lober. Além dos europeus que moravam em Dar es Salaam, o concerto natalino foi assistido por grande número de passageiros do "Herzog" (DOAZ, 30.12.1899, p. 3). Menos de dez anos após a incorporação de Dar es Salaam ao império alemão já havia também uma associação de canto cujos ensaios se realizavam numa sala do Casino (DOAZ, 26.02.1899, p. 3). Aliás, os alemães e demais europeus se reuniam neste casino não apenas para jogar e beber, mas também para assistir eventuais concertos, programas de variétés, inclusive exibição de cinematógrafo, etc. Outro local da vida social em Dar es Salaam era a primeira cervejaria alemã, fundada em 1897.

Além das práticas de sociabilidade diárias ou semanais que ocorriam nos salões dos estabelecimentos hoteleiros, outras aconteciam em eventos mensais ou anuais tanto nesses locais quanto nas ruas, em praças ou mercados, etc.

Nas cidades portuárias como Dar es Salaam, Swakopmund ou na Baía de Lüderitz, a presença de navios alemães (mercantes ou de guerra) era um sinônimo de uma vida social ativa, pois os passageiros e especialmente os oficiais e marinheiros participavam de competições esportivas, de festas religiosas ou civis, além de 
frequentar os salões de hotéis, restaurantes, bares e cafés dessas cidades portuárias.
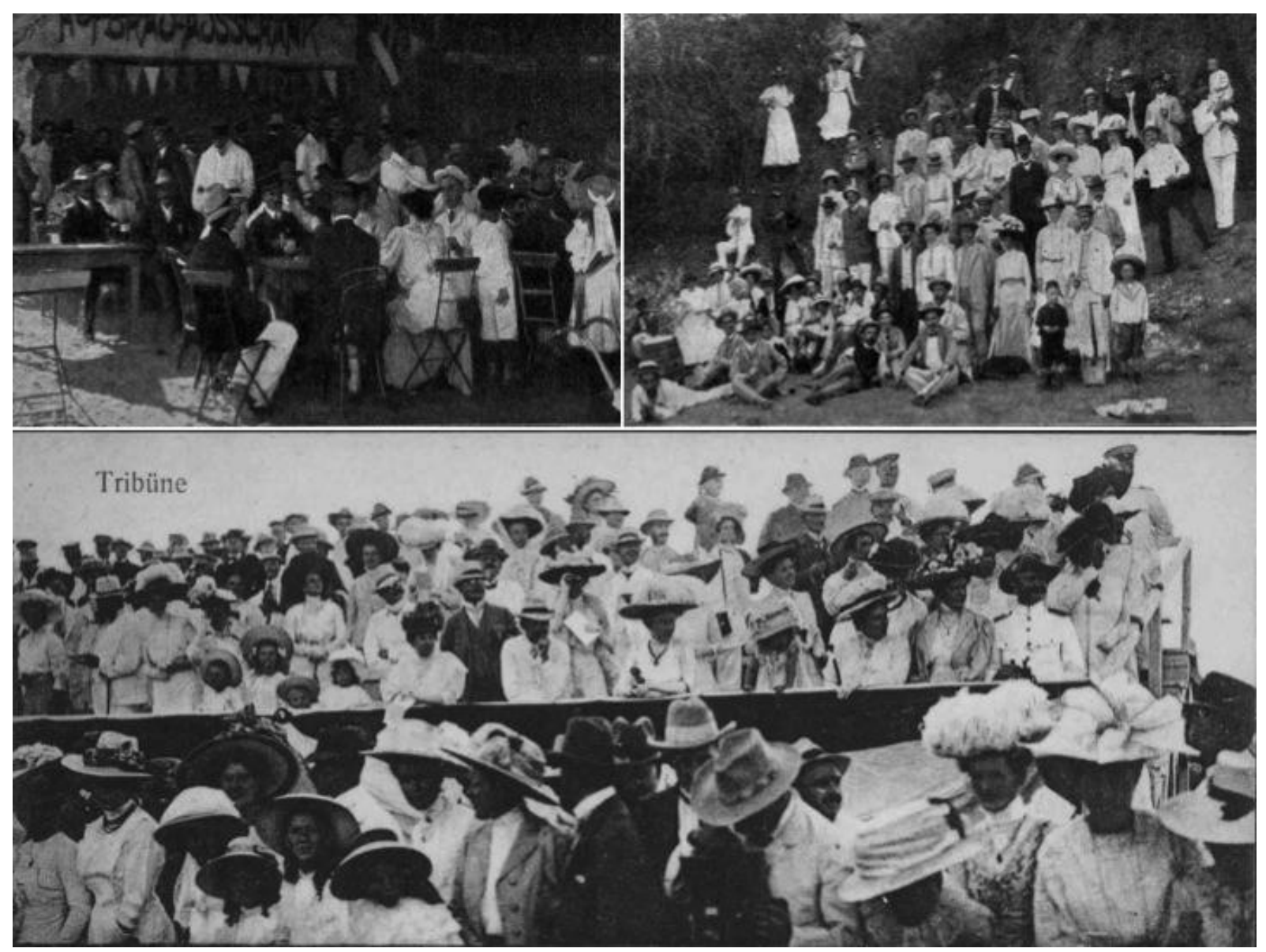

Figura 1 - Três imagens de cenas de sociabilidades na então colônia alemã do sudoeste africano (atual Namíbia). A primeira fotografia mostra um momento de descontração em meio a muita cerveja numa festa na cidade portuária de Swakopmund ("Bierkonzert beim Schützenfest in Swakopmund", in: Kolonie und Heimat in Wort und Bild, Nr. 14, Berlin, 25.12.1910, S.06); a segunda registra um passeio, promovido por uma sociedade local ("Vereinausflug in Südwest", in: Kolonie und Heimat in Wort und Bild, Nr. 14, Berlin, 25.12.1910, S.07); e, a terceira registra a tribuna de uma corrida de cavalos em Windhoek ("Rennbahn in Windhoek", Koloniales Bildarchiv der Universitätsbibliothek Frankfurt, Nr. 080-2996-153).

Momentos de intensa vida social nas colônias alemãs eram as festas em torno de um evento religioso como Pentecostes, Páscoa ou Natal. Nessas festividades, as sociedades esportivas organizam algumas competições. Um esporte muito prestigiado na colônia alemã do sudoeste africano foi a corrida de cavalos. As corridas eram uma ocasião ímpar à sociabilidade, inclusive feminina (BROCKMANN, 1912, p. 131-132). Muitos eventos esportivos, como corridas de cavalos, e recreativos, como piqueniques e passeios, eram organizados por associações locais, o que imprimia outro ritmo, um novo tempo na vida social dos alemães na África colonial.

O balbuciar das práticas de sociabilidades nas colônias se dava por um grupo não muito homogêneo em termos sociais e culturais. Apesar da maioria ter a mesma 
nacionalidade alemã, a origem social e regional era variada. Vale lembrar que a unificação alemã precedeu pouco menos de 15 anos o colonialismo alemão na África. Alguns imigrantes alemães tinham nascido antes da guerra franco-prussiana e muitos não falavam o alemão padrão. Naquela época, os sinais diacríticos distinguiam facilmente um prussiano de um bávaro, um pomerano de um renano. Durante as festas na colônia alemã do sudoeste africano eram comuns as piadas entre alemães, inclusive em dialeto ( $L Z, 10.07 .1914$, p. 2). Apesar das idiossincrasias, os alemães formavam um grupo coeso diante dos grupos étnicos africanos. Cabe ainda lembrar que o nacionalismo e o pangermanismo fomentavam uma identidade alemã cultivada por várias associações.

Apesar da identidade alemã ter forte apelo entre as associações, ela não anulou a clivagem social que havia na comunidade de alemães na Baía de Lüderitz. Diante do pequeno número de alemães, os poucos que já faziam parte da elite prussiana ou bávara tiveram que conviver com seus compatriotas de origem regional diversa, além da origem social distinta, burguesa ou plebeia. ${ }^{3} \mathrm{Em}$ certos lugares públicos como cafés ou salões de baile, isso favoreceu um sociabilidade entre alemães pautada pelas circunstâncias e talvez ainda mais por uma questão de identidade nacional (e racial) do que por uma afinidade de classe. Nesses lugares mais propícios às práticas de sociabilidade, como o café ou o salão de um hotel numa cidade portuária na África colonial, era comum a composição de um "buquê social" - para usar uma expressão proustiana - com elementos socialmente heterogêneos. ${ }^{4}$

Para uma maioria de alemães na África colonial, pode-se inferir que algumas formas de sociabilidade foram práticas de emulação de convívio social urbano da Alemanha do II Reich. Para os alemães que migraram para o sudoeste africano em busca de enriquecimento, a vida social favorecia a representação de um certo ideal de ordem social menos rígida, por conseguinte, de maior mobilidade. Inclusive, a literatura colonial contribui para a representação imaginária da África como Eldorado, o que suscita indagações sobre o lugar das ficções literárias nos padrões de comportamento, na fuga fantasiosa da rotina e na busca da evasão (BRESCIANI, 2010, p. 14).

Para alguns, a África representava o "fardo do homem branco". Para outros, o

\footnotetext{
${ }^{3}$ Em 1912, a população branca no sudoeste africano não ultrapassava 15.000 pessoas. A maioria era de origem alemã. Esse número representava, no entanto, quase 3 vezes mais o número de brancos na África Oriental Alemã (WESSELING, 2005, p. 364).

${ }^{4}$ Au reste, Swann ne se contentait pas de chercher dans la société telle qu'elle existe et en s'attachant aux noms que le passé y a inscrits et qu'on peut encore y lire, un simple plaisir de lettré et d'artiste, il goûtait un divertissement assez vulgaire à faire comme des bouquets sociaux en groupant des éléments hétérogènes, en réunissant des personnes prises ici et là. Ces expériences de sociologie amusante (ou que Swann trouvait telle) n'avaient pas sur toutes les amies de sa femme - du moins d'une façon constante - une répercussion identique (PROUST, 1988, p. 92).
}

URBANA, V.4, n05, dez.2012 - Dossiê: Cidades e Sociabilidades - CIEC/UNICAMP 
continente guardava tesouros incomensuráveis. Essas imagens não eram antagônicas e ambas estavam presentes na literatura colonial. ${ }^{5}$ Aliás, a literatura colonial era engajada, um veículo de propaganda da expansão colonial (WASSINK, 2004 p. 131132). Tal literatura justificava a exploração da África como forma de recompensa a todo o custo do "empreendimento civilizatório" da Europa. Mas havia também um apelo à aventura, a uma chance imperdível que atraiu bastante europeus que já tinham perdido tudo ou quase tudo ou que não tinham mesmo muito a perder.

Para as práticas de sociabilidade entre alemães na África colonial, pode-se dizer que as aparências contavam muito, talvez mais que a própria origem social que podia se manter incógnita sob novas formas de comportamento, etiqueta, etc. ${ }^{6} \mathrm{Na}$ África colonial, em geral, os imigrantes alemães se sentiam livres para agir de modo diferente. Andar a cavalo, poder caçar e ter criados para dar ordens eram algumas das novas experiências, pretensamente aristocráticas. Ao mesmo tempo, a vida social "entre os pares" era uma forma de lubrificar as engrenagens das aspirações pessoais e do próprio domínio colonial. Aliás, o colonialismo contou com a solidariedade dos emigrados, com a comunhão de interesses no além-mar daqueles imigrantes com o seu Estado de origem, se é que se pode generalizar a observação do historiador David K. Fieldhouse (apud SAID, 2001, p. 46-46) sobre a relação da atitude mental do colono com o imperialismo.

Ideologicamente, os alemães se viram como uma "raça de senhores" (Herrenrasse) na África colonial, mas isso não significou o completo esmaecimento das origens sociais ou mesmo do status variado de um comissário imperial ou de um colono alemão. Desse modo, as sociabilidades acusam, ao mesmo tempo, aproximações e distanciamentos sociais e culturais. Mesmo que as sociabilidades permitiam "baixar a barreira social" entre alguns, a vida social na "África alemã" não era equânime para jovens e adultos, homens e mulheres e muito menos para adventícios e nativos.

Para os alemães do sudoeste africano, o germanismo (Deutschtum) foi um elemento fundamental da identidade coletiva. Mas os "laços de sangue" não bastavam

\footnotetext{
${ }^{5}$ Da literatura colonial em língua alemã, pode-se dizer que, numa primeira fase (1884-1904), houve certa euforia em relação aos domínios ultramarinos; numa segunda (1904-1919), predominou o tema da conquista, do exótico que deveria ser domesticado; numa terceira (1919-1933), apareceu certa nostalgia relacionada à perda das colônias; e, numa quarta e última fase (1933-1945), houve uma espécie de retórica da compensação, pela qual as narrativas literárias sobre as colônias à época do imperialismo ultramarino do II Reich balizavam aspirações de um imperialismo continental do III Reich (WASSINK, 2004, p. 133-135).

${ }^{6}$ Para ficar num exemplo, o médico alemão Karl Schinke (2009, p. 211) tinha dificuldades em saber a origem de um militar da Schutztruppe durante a guerra colonial no sudoeste africano. Em carta para a sua esposa, escreveu o médico: "Miliczewski continua sendo uma incógnita. Será que ele é polonês, ou não é? A história da nobreza da Pomerânia, ele conhece melhor que qualquer um".
} 
para unir os alemães na África. Foram as associações locais que organizaram grande parte da vida social em Windhuk, Swakopmund, na Baía de Lüderitz e demais localidades do sudoeste africano. Essas associações tiveram supina importância para a organização da incipiente sociedade colonial uma vez que outras instituições tiveram dificuldades em estender seu controle ou mesmo em se fazer presentes nos confins do império.

$\mathrm{Na}$ língua alemã, o termo Verein significa associação. Ao contrário das palavras clube ou sociedade, associação é um termo mais "neutro" em alemão (MEYER, 2006, p. 8). Apesar disso, valer-se das associações para fins políticos era proibido por uma lei prussiana desde o final do século XVIII. A relação tensa entre Estado e associações na Alemanha se expressou nas próprias leis e regulamentações, notadamente entre 1848 e 1871. Desde meados do século XIX, a diversificação e a alteração das associações e, por conseguinte, das sociabilidades foram concomitantes a outras mudanças na estrutura social, promovidas pela industrialização e pela urbanização; isto é, pela modernização da Alemanha. Novas demandas não eram supridas pelas instituições tradicionais como família e igreja. De modo geral, as associações procuraram resolver a questão social do século XIX. Apesar do controle policial, por muitas associações circularam ideias políticas, enquanto outras já foram fundadas sob o signo do socialismo ou da socialdemocracia. Até 1914 houve um enorme crescimento das associações na Alemanha (MEYER, 2006, p. 15-16). Se a história política das associações na Alemanha se equivale, grosso modo, com a evolução dos círculos burgueses na França, pode-se inferir que houve similar desdobramento em termos de sociabilidade.

Mas na colônia alemã do sudoeste africano, as associações foram exclusivamente conservadoras em termos políticos. Diferente da Alemanha, onde o movimento dos trabalhadores fomentou em suas associações o socialismo ou a socialdemocracia, na África sob domínio colonial a maioria dos trabalhadores estava excluída da vida associativa. As associações eram exclusivamente para brancos e seus fins se coadunavam com a manutenção da ordem colonial. E como observou Hannah Arendt (1989, p. 237), "as possessões coloniais africanas tornaram-se o solo mais fértil para que florescesse o grupo que viria a ser mais tarde a elite nazista."

Em termos gerais, tanto na Alemanha do II Reich quanto na colônia alemã do sudoeste africano, a associação era um agrupamento social voluntário e que tinha um objetivo comum e duradouro. Sua função social era reconhecida juridicamente, bem como o seu nome. A associação oferecia aos seus membros atividades regulares (MEYER, 2006, p. 19). 
A linguagem dessas associações acusa uma vida social moderna. Não eram elas confrarias ou meros grupos de amigos, mas instituições locais que se mantinham através de mensalidades ou anuidades cotizadas pelos seus membros. Logo, não se tratam mais de relações informais entre confrades ou amigos, mas formalizadas, entre membros. Mais uma vez, a linguagem conduz à realidade (AGULHON, 2009, p. 99).

\section{Os lugares das sociabilidades na Baía de Lüderitz}

Localizada na costa da atual Namíbia, a Baía de Lüderitz foi um dos primeiros empórios alemães na África. O nome do local remete à figura do comerciante de Bremen, Franz Adolf Eduard Lüderitz (1834-1886). Em 1884, essa pequena baía na costa desértica da Namíbia foi incorporada ao império alemão. No final do século XIX, a economia local era basicamente extrativa, tendo destaque o guano. Após as guerras coloniais no sudoeste africano (1904-1907), a vida associativa local conheceu uma fase próspera com surgimento de novas associações na década de 1910. Porém, a Primeira Guerra Mundial teve um impacto imediato na vida associativa dos alemães já que as tropas sul-africanas invadiram a Baía de Lüderitz em setembro de 1914.

Durante os primeiros 25 anos, a vida social na Baía de Lüderitz foi pouco atrativa para aqueles habituados à vida mundana em Berlim ou Munique. O pequeno povoado em torno daquele porto marítimo do sudoeste africano dependia de água potável proveniente de alhures; inclusive da Colônia do Cabo, de onde chegava em navio-cisterna. Mas a descoberta de diamantes em 1908 fomentou uma grande expectativa em relação ao futuro da colônia alemã do sudoeste africano, fazendo surgir um povoado nas areias do deserto. Geograficamente, o porto marítimo era favorecido por uma pequena angra. Devido principalmente à exploração do diamante, a escala na Baía de Lüderitz se tornou quase obrigatória entre o porto de Swakopmund e a Colônia do Cabo.

Tanto para aquelas pessoas de passagem pela Baía de Lüderitz quanto para aquelas que moravam no local, os salões dos primeiros hotéis, restaurantes e cafés foram os principais espaços de sociabilidades. Já no final do século XIX, a vida social mundana passava a coexistir com aquela restrita às missas e aos cultos, às festividades religiosas, etc. Católicos e protestantes alemães também passaram a conviver com bôeres calvinistas e ainda alguns britânicos de religião anglicana. Ao tempo das festividades religiosas foi se ajustando um calendário esportivo e comemorativo e que passou a orientar a maioria das práticas de sociabilidade.

Na Baía de Lüderitz, os salões dos hotéis foram o principal lugar das 
sociabilidades. Neles eram realizadas as reuniões da maioria das associações locais. Os proprietários dos hotéis organizavam, por seu turno, uma série de atrações culturais, artísticas e sociais não apenas para seus hóspedes, mas principalmente para a comunidade local. Com base nos anúncios do jornal local (Lüderitzbuchter Zeitung), pode-se inferir que os hoteleiros foram os principais promotores das sociabilidades que transcorriam, em grande parte, nos salões e demais dependências dos hotéis. ${ }^{7}$

Kapps Hotel, Hotel Rösemann e Hotel Europäischer Hof foram os principais estabelecimentos hoteleiros da Baía de Lüderitz. O empreendimento hoteleiro era, todavia, um negócio. A prestação de serviços tinha que ser rentável. Caso contrário, um hotel podia mudar de proprietário, o estabelecimento fechar, etc. Mudança de proprietários, fechamento de estabelecimentos hoteleiros e inaugurações de novos hotéis, cafés ou restaurantes ocorreram no sudoeste africano, notadamente na Baía de Lüderitz. Para dar alguns exemplos, o senhor Bütow, sócio proprietário do Kapps Hotel comprou um hotel em Swakopmund ( $L Z, 16.04 .1910$, p. 7). Em dezembro de 1910, o senhor Eckert assumiu o Hotel Europäischer Hof (LZ, 31.12.1910, p. 4).Um ano depois, foi a vez de Paul Rolle comprar o mesmo hotel (SZ, 02.12.1911, p. 3). Passados dez anos, o senhor Rolle comprou o Central-Hotel que havia sido colocado à venda após a morte do seu proprietário Karl Christian Friedrich Bannau (LZ, 04.04.1922, p. 2). Essas mudanças tinham, provavelmente, impacto sobre a vida social. Por outro lado, algumas associações mudavam o local de suas reuniões, o que suscita questionamento sobre as relações entre membros das associações e proprietários dos hotéis ou restaurantes.

Conforme uma nota no Guia de endereços do distrito da Baía de Lüderitz de 1914, os membros da associação masculina de canto (fundada em 1909) se reuniam toda a quinta-feira à noite no salão do Kapps Hotel. Neste local, a associação fazia algumas apresentações ( $L Z, 18.12 .1909$, p. 3). No Kapps Hotel, a mesma associação comemorou o seu primeiro aniversário, com jantar na sexta-feira, concerto no sábado e baile no domingo ( $L Z, 13.08 .1910$, p. 2-3). No jornal local circulavam também notícias sobre outras reuniões nas dependências do Kapps Hotel, como a do clube de futebol (LZ, 24.04.1909, p. 4).

O estabelecimento hoteleiro de propriedade de Bütow e Bauer tinha uma sala de concerto para 400 pessoas. Nela eram realizados bailes e concertos musicais, bem como apresentações de peças teatrais. Troupes e ensembles da Europa também se

\footnotetext{
${ }^{7}$ Essa iniciativa do empreendimento hoteleiro não se deu apenas no contexto da África colonial. Similar atuação dos hoteleiros de origem alemã também foi objeto de estudo sobre a vilegiatura marítima no Brasil meridional. Em sua dissertação de mestrado, Joana C. Schossler atentou para certas áreas de hotéis (restaurantes, salão de baile, casinos, etc.) como espaços de sociabilidade de algumas praias balneárias. Cf. (SCHOSSLER, 2010).
}

URBANA, V.4, n05, dez.2012 - Dossiê: Cidades e Sociabilidades - CIEC/UNICAMP 
apresentavam no Kapps Hotel, como, por exemplo, a noite de cabaré com animação de um ensemble de Leipzig (LZ, 31.07.1909, p. 7). Depois da apresentação houve ainda um baile que durou até 0 amanhecer. Os artistas de Leipzig também se apresentaram no Europäischer Hof (LZ, 07.08.1909, p. 2).

Havia ainda outra grande sala com mesas de bilhar francês e inglês no Kapps Hotel. A filial local da Liga Feminina da Sociedade de Colonização Alemã fazia também reuniões no Kapps Hotel, sendo o espaço das reuniões o andar superior do hotel, onde as mulheres poderiam se encontrar, provavelmente, sem os eventuais constrangimentos no hall principal do primeiro piso, onde se concentrava o público masculino (LZ, 18.09.1911, p. 4).

Em anúncios do estabelecimento hoteleiro de Bütow e Bauer se destacavam a variedade e a qualidade de bebidas espirituosas importadas e a conveniência do local para encontros de colecionadores de diamantes e interessados em mineração (LZ, 15.05 .1909 , p. 7). Cabe ressaltar que o tipo e o preço das bebidas oferecidas traduzem uma estratégia seletiva do público que frequentava o estabelecimento e, por conseguinte, uma forma de controle da vida social.

O espaço hoteleiro era também lugar de reuniões políticas, de debate entre eleitores e candidatos às eleições locais como ocorreu no salão do Kapps Hotel em início de outubro de 1909. Para essa reunião era esperado um número em torno de 200 pessoas tal como ocorreu no debate anterior (LZ, 02.10.1909, p. 2). ${ }^{8}$ Em janeiro de 1910, a sala do Kapps Hotel também serviu para uma grande reunião dos funcionários da administração colonial para encaminhar uma solução política diante da carestia do custo de vida (LZ, 01.15.1910, p. 2).

\footnotetext{
${ }^{8}$ Outra reunião para as eleições comunais se realizou no Kapps Hotel em 14 de outubro de 1909 (LZ, 09.10.1909, p. 4). Nova reunião para eleições do conselho municipal ocorreu no Kapps Hotel na primeira semana de abril de 1910 (LZ,02.04.1910, p. 1-2). 

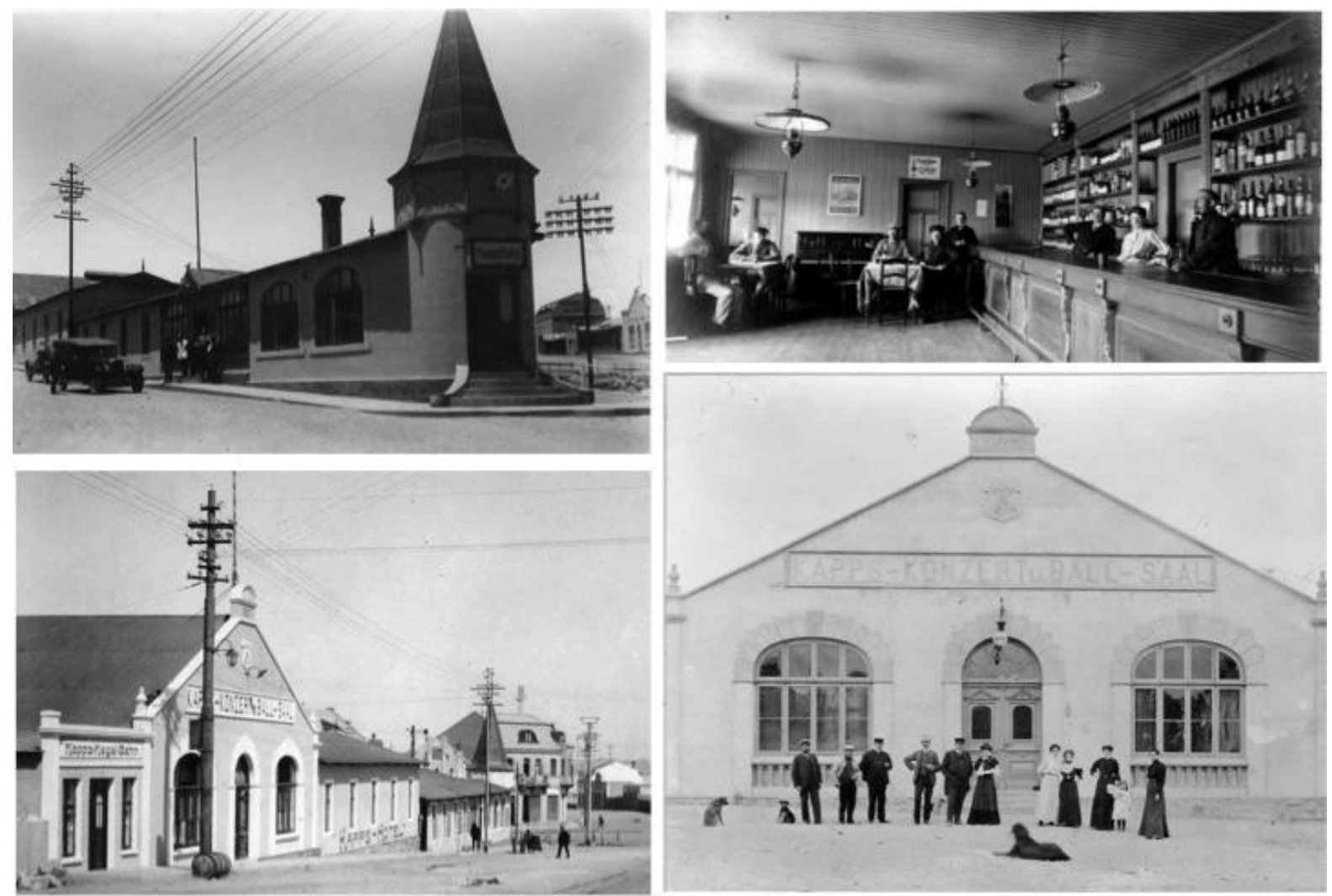

Figura 2 - Frente do Kapps Hotel (1), um dos principais espaços de sociabilidade na Baía de Lüderitz. Ao Iado, Bar do Kapps Hotel (2). Em anexo à Sala de Concerto e Baile do Kapps Hotel (4), pode-se ver a sala de boliche (3).

Fonte: National Archive of Namibia, Windhuk.

Outros estabelecimentos hoteleiros concorriam com o Kapps Hotel pela preferência das associações e membros da comunidade da Baía de Lüderitz. No Rösemann Hotel havia também reuniões da sociedade de moradores para discussão de questões políticas, inclusive com a presença do prefeito local (LZ, 02.07.1910, p. 2). Segundo o já referido Guia de endereços do distrito da Baía de Lüderitz (1914), outras associações tinham seus encontros regulares no salão do Hotel Rösemann, como o clube de xadrez (fundado em 1910) toda sexta-feira à noite. No mesmo local, mas em dias distintos, se encontravam os membros da associação dos marinheiros (fundada em 1910) e da associação dos baloeiros (fundada em 1913). Mas os membros da primeira também tinham encontros etílicos no Kapps Hotel. Para ficar num exemplo, a noite da cerveja (Bierabend) realizada num sábado à noite em meados de 1910 ( $L Z, 25.06 .1910$, p. 8).

Membros da União dos Comerciantes (fundada em 1912) também se reuniam no salão do Hotel Rösemann, assim como os veteranos da associação dos combatentes (fundada em 1906). O proprietário do Hotel Rösemann também promovia alguns jantares, bailes e festas. No Natal de 1913, por exemplo, os 
hóspedes tiveram um jantar natalino que foi alvo de comentário no jornal local (LZ, 20.11.1909, p. 10). Ainda as festas de aniversário de notoriedades locais ocorriam naquele local (LZ, 29.01.1910, p. 2).

No Hotel Rösemann havia um bilhar francês para hóspedes e habitués. Encontros para o jogo de bilhar eram anunciados no jornal local. O fato de haver uma lista prévia de jogadores permite inferir que o espaço físico e/ou o número limite de participantes era menor do que o número de interessados. Também no Central-Hotel havia um bilhar francês. Suas "modernas salas sociais" e "apropriadas para grandes e pequenas festividades" eram mencionadas em anúncio no jornal local.

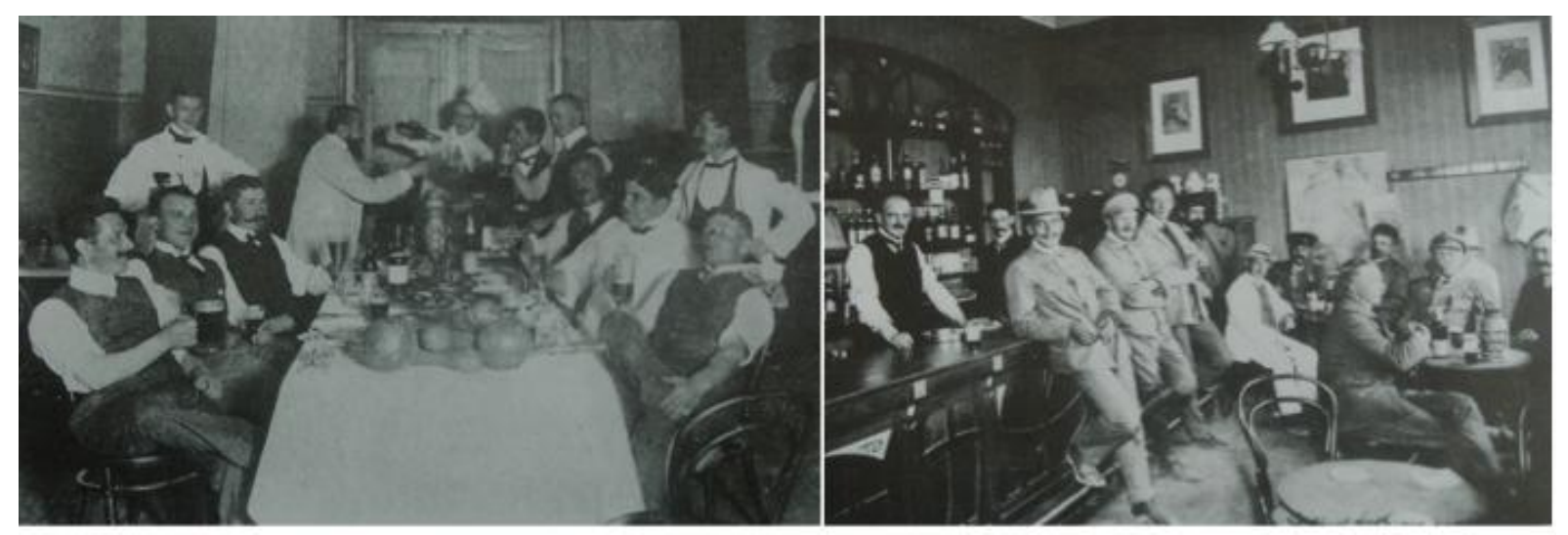

Figura 3 - Duas cenas de práticas de sociabilidade em salões de hotéis na Baía de Lüderitz: Uma confraternização após jogo de boliche no Kapps Hotel (esquerda) e uma cena ordinária no bar do hotel Europäischer Hof (direita).

Fonte: Lüderitzbucht damals und gestern, 1998.

No salão do hotel Europäischer Hof costumavam se encontrar os membros de uma associação de proprietários de casas e terrenos da Baía de Lüderitz (fundada em 1912). Também a maior associação de comércio se reunia no mesmo salão. Conforme anúncio no jornal local, o hotel garantia aos seus hóspedes vinhos e cervejas das melhores casas. Programas artísticos eram realizados nas dependências do hotel, com preços módicos, às vezes com entrada livre ( $L Z, 09.10 .1909$, p. 4). Com ingressos no valor de 5 marcos e lugar reservado por 6, o público poderia assistir a exibição do cinematógrafo ( $L Z, 18.12 .1909$, p. 7). Festas eram também promovidas como a Bockbierfest, com mais de cem convivas e animada música com piano, violino e trompete (LZ, 10.07.1914, p. 2). A Sociedade de Teatro (fundada em 1910) também fazia suas reuniões e seus ensaios nas dependências do Europäischer Hof.

Destaca-se nos anúncios de certos estabelecimentos a gama de bebidas importadas, desde o vinho do Porto, o champanhe de Reims e os vinhos do Reno, além de vermutes, cervejas, etc. A oferta de bebidas estrangeiras e alemãs nos 
restaurantes, hotéis e empórios locais acusa uma procura por parte de consumidores já habituados às bebidas alcoólicas metropolitanas. Aliás, assim como o tabaco, a bebida espirituosa era um elemento constitutivo da sociabilidade masculina.

Além das reuniões hebdomadárias, quinzenais ou mensais de algumas associações, salões de hotéis e de restaurantes acolhiam também outras atividades lúdicas e/ou sociais como leilões e loterias. No jornal de Lüderitz foi anunciado um encontro do Clube da Loteria a ser realizado no Restaurant zur Börse, na noite de quinta-feira 13 de maio de 1909. Pedia-se pontualidade aos membros do clube (LZ, 08.05.1909, p. 4). Outra loteria ocorreu na noite do primeiro domingo de dezembro no Central-Hotel (LZ, 11.12.1909, p. 2).

Raras entidades tinham sedes próprias como o Clube de Tênis. Os membros da sociedade de ginástica faziam seus exercícios físicos duas vezes por semana nas dependências do Kapps Hotel. A sociedade de ginástica participava também de vários eventos da comunidade local, sendo ela um importante elemento da vida social dos alemães no sudoeste africano (CORREA, 2012).

Alguns hotéis ofereciam seus espaços e equipamentos para práticas esportivas como, por exemplo, o hotel Germânia. Seu proprietário era Edmund Schmidt. Devido à sua localização um pouco afastada do centro da cidade, o anúncio do hotel ressaltava o ambiente calmo e tranquilo para convalescentes e famílias. Nota-se um apelo em imitar estilos de vida de outrora reservados a classes privilegiadas que possuíam propriedades rurais e nelas viviam parte do ano. ${ }^{9}$ Apesar da referência à emulação social, vale lembrar que a África foi para os imigrantes alemães um lugar de oportunidades, onde podia se tornar um grande proprietário e ter vários criados. Como se fosse um senhor feudal, podia-se caçar nos próprios domínios e frequentar salões de forma pretensamente aristocrática.

Os salões dos hotéis ou restaurantes eram, portanto, locais de confluência de duas tendências: uma que aspirava ainda práticas aristocráticas e outra mais de expressão burguesa. Por isso, os espaços de sociabilidade como os salões de hotéis abrigavam atividades como concertos, espetáculos, bailes, jogos e reuniões associativas que imiscuíam, muitas vezes, as tendências, resultando numa vida social de eclético estilo colonial.

Outros locais de sociabilidade eram os cafés. Inclusive, havia um Casino-Café aberto dia e noite. Também havia o Café Bauer, do proprietário Carl Becker, composto ainda por confeitaria e padaria. Outra confeitaria e padaria era a de Karl Hallerbäumer.

\footnotetext{
${ }^{9}$ Como observou Eugen Weber $(1988$, p. 217) para a França fin-de-siècle, essa mímica social por parte daqueles que dispunham de recursos para passar um tempo no campo ou à beira-mar tinha a ver com a própria representação do retiro, da vilegiatura campestre ou marítima.
} 
Em meados de 1910 passou a funcionar o Café Bismarck, sob a direção da Fraulein Kroll (LZ, 02.07.1910, p. 12). Aliás, anúncios de jornais registram outras mulheres como proprietárias de restaurantes, cafés e hotéis na colônia alemã do sudoeste africano. Para ficar num exemplo, o Café Metropol de Frau Zicker foi inaugurado em novembro de 1915 (LZ, 15.11.1915, p. 1).

Naquela pequena cidade portuária, outro local de sociabilidade era o recinto para banhos de mar (Seebad-Anstalt), inaugurado em meados de 1909. A sociedade de banhos gastou 3.000 marcos para deixar o local apropriado para os banhistas, inclusive com barreiras para proteção dos ventos e das areias; afinal, os meses de dezembro, janeiro e fevereiro eram conhecidos como estação dos ventos; o que, aliás, tolhia não apenas o prazer dos banhistas como também o prazer dos aficionados pelas corridas de cavalos (LZ, 16.07.1910, p. 9). Também foram construídas cabines para vestiários, duchas com água doce e trampolim. Uma taxa para entrada custava 50 centavos ou 6 marcos de mensalidade para associados. Os horários de frequentação variavam para homens e mulheres e também para os dias da semana e para os sábados, domingos e feriados. À venda no local havia café, chá, água mineral e outras bebidas para o consumo dos banhistas. (LZ, 17.07.1909, p. 2)
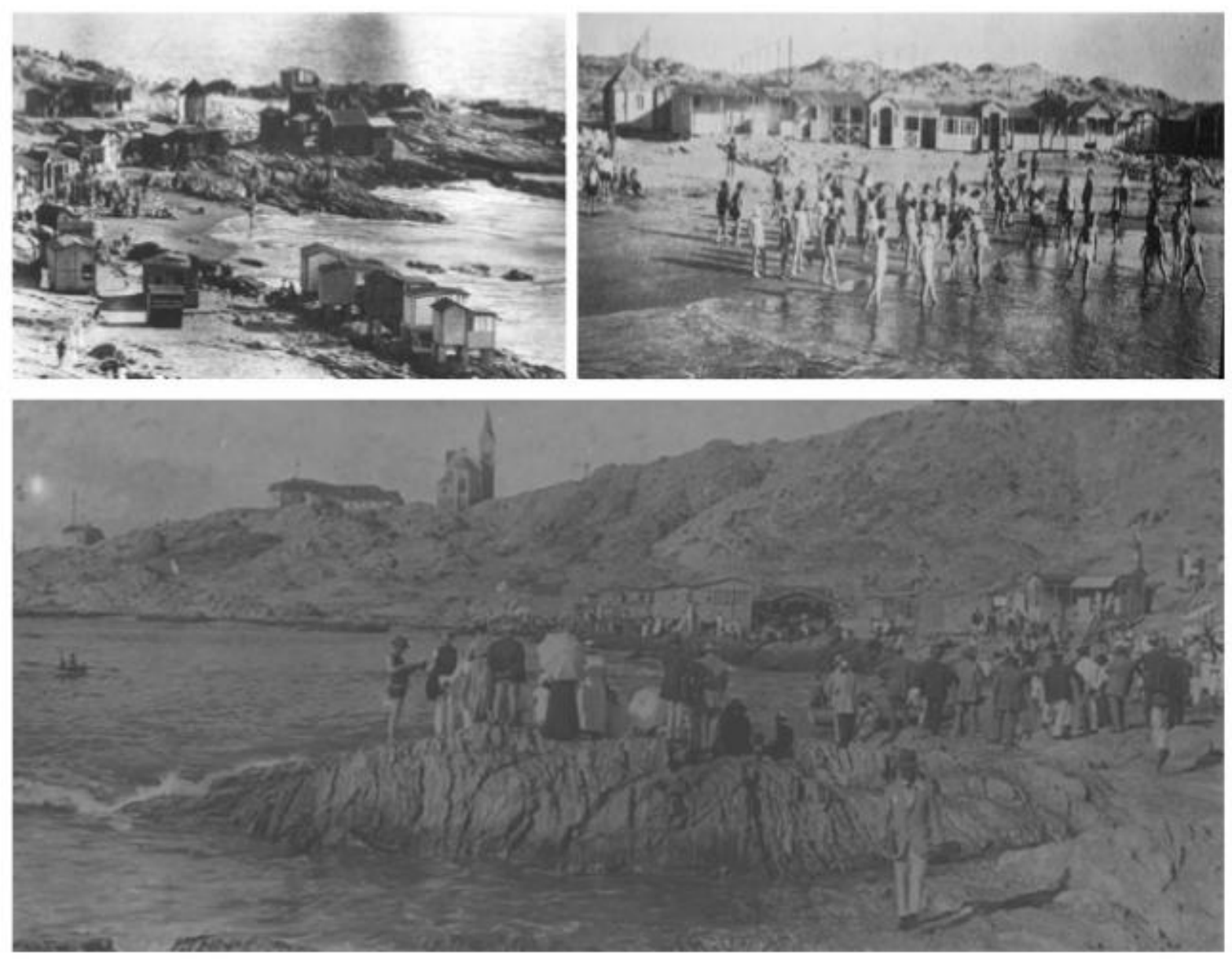

Figura 4 - Três cenas de sociabilidades na praia de banhos na Baía de Lüderitz. Esquerda (sem data): National Archive of Namibia (Windhoek) Photo Nr. 06214; Direita (sem data): Lüderitz als Seebad und URBANA, V.4, n05, dez.2012 - Dossiê: Cidades e Sociabilidades - CIEC/UNICAMP 
Erholungsort. Herausgegeben von der Stadverwaltung (National Library of Namibia); Abaixo: Festa na praia (Strandfest) Koloniales Bildarchiv der Universitätsbibliothek Frankfurt, Nr.041-0241-54

No entanto, a organização e controle dos banhos de mar por meio de uma associação não tiveram muitos resultados. Os ventos, a areia, o forte calor, a alta salinidade da água e a intensa luminosidade foram alguns dos fatores que contribuíram para o fracasso do balneário. A presença de tubarões naquelas praias era outro fator inibidor à ida aos banhos de mar (BROCKMANN, 1912, p. 124). Em 1912, uma matéria no jornal local tratou do déficit do estabelecimento balneário e fez um apelo aos leitores para frequentarem o local (LZ, 09.03.1912, p. 14).

Apesar de uma série de fatores inibidores à prática dos banhos de mar, a orla tinha outros atrativos, como o porto e os moles. Passeios a pé ou a cavalo até a praia eram organizados por algumas associações, como o passeio organizado pela associação de moradores até a baía Griffith, nas cercanias da baía de Lüderitz, e cujo objetivo era "promover a sociabilidade (Geselligkeit) entre os membros e seus convidados" (LZ, 02.07.1910, p. 2).

Além da praia e do porto marítimo e dos salões dos hotéis centrais, outros espaços serviam para a prática de sociabilidades. No Hotel Germânia, por exemplo, havia um campo onde ocorriam "quase diariamente" partidas de futebol e golfe (LZ, 10.04.1909, p. 6). Seu proprietário, o alemão P. Hemmerich, era um entusiasta dos esportes. Chegou a reunir em seu hotel um grupo de amadores para fundar uma associação esportiva com o fito de promover o futebol, o cricket e outras atividades atléticas como a corrida, o salto e o box (LZ.14.02.1913, p. 4). O campo nas cercanias da cidade também era procurado para atividades esportivas como a caça ou para os exercícios de tiro. Assim, os lugares ermos eram também representados como espaços a ser controlados pelas práticas de sociabilidade masculina.

\section{Sociabilidades em diferentes tempos}

Os salões dos hotéis não eram locais apenas reservados às atividades das associações e clubes. Seus proprietários também ofereciam uma série de atividades culturais, recreativas, sociais, etc. O Kapps Hotel realizava grandes bailes. Também eram realizados mensalmente torneios, sobretudo de jogos de cartas. Em alguns bailes promovidos pelo Kapps Hotel, mulheres não pagavam entrada, o que se justificava pela "raridade" delas, segundo matéria do jornal local (LZ, 19.06.1909, p. 2). Nas páginas do hebdomadário também se lamentou a reduzida presença feminina na "Noite Italiana" realizada no Kapps Hotel ( $L Z, 21.08 .1909$, p. 2). A desculpa foi o temporal. Por isso, a "Noite Italiana" foi realizada novamente com entrada livre para 
as mulheres. Também com entrada livre para o público feminino foi a grande reunião dançante no Kapps Hotel no primeiro domingo de dezembro de 1909.

Pode-se inferir pela frequência regular dessas atividades nas dependências hoteleiras que elas estruturam a vida social da Baía de Lüderitz. Tanto homens e mulheres quanto adultos e crianças encontravam atrações de lazer nos salões dos hotéis. Para o público masculino, por exemplo, o Central Hotel oferecia um dos melhores bilhares da cidade. No último torneio de 1910, 14 homens participaram (LZ, 09.10.1910, p. 2). Também nas dependências "arejadas e elegantes" do hotel de Hugo Schönert se realizava encontros para jogo de cartas, como na noite de 20 de dezembro de 1910, que reuniu 30 senhores ( $L Z, 24.12 .1910$, p. 2).

No Hotel Europäischer Hof, as sessões de cinematógrafo nas noites de quartafeira e domingo e as matinés no sábado atendiam respectivamente o público adulto e infantil ( $L Z, 09.10 .1910$, p. 2). Para dar mais um exemplo, a Sociedade de Teatro local fez uma apresentação cênica para o público infantil no Kapps Hotel no final de 1910 (LZ, 31.12.1910, p. 2).

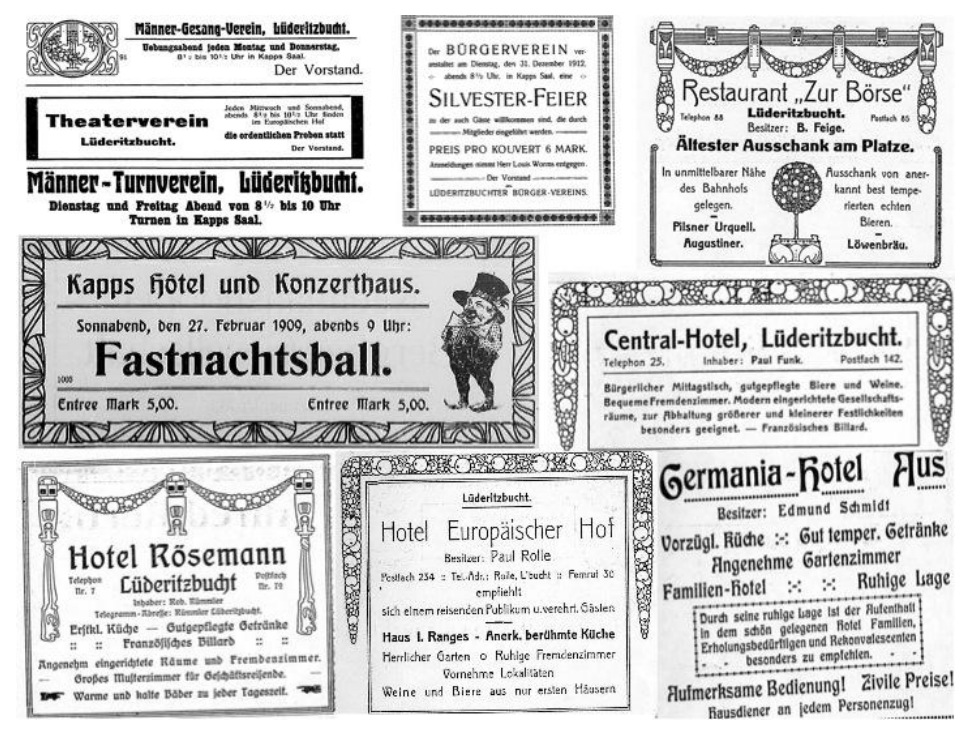

Figura 5 - Anúncios de restaurantes e hotéis da Baía de Lüderitz, lugares de sociabilidades onde uma série de atividades de sociedades recreativas ou esportivas eram realizadas, além de concertos, bailes, etc.

As sociabilidades se manifestavam ainda em ocasiões especiais como eventos 
comemorativos e esportivos. Anualmente, as colônias alemãs festejavam o aniversário do imperador. Na Baía de Lüderitz, algumas associações se reuniam para organizar a Festa do Kaiser. Em fevereiro de 1909, os 50 anos do imperador Guilherme II foram comemorados por 300 pessoas no salão do Kapps Hotel, onde os presentes entoaram canções patrióticas (LZ, 13.02.1909, p. 1). Em final de janeiro de 1910, a sala do Kapps Hotel foi ocupada por pais e familiares dos escolares que fizeram pela primeira vez uma apresentação em homenagem ao aniversário do Kaiser (LZ, 05.02.1910, p. 2).

Em fevereiro de 1910, o hasteamento da bandeira da associação dos combatentes foi uma verdadeira "festa popular", conforme notícia do jornal local da Baía de Lüderitz. Além da participação de outras associações, a festa popular teve encerramento no salão do Kapps Hotel ( $L Z, 12.02 .1910$, p. 2). O carnaval também era uma festa que se realizava nos salões dos hotéis. O Kapps Hotel organizava anualmente um grande baile de máscaras.

Durante o feriado de Páscoa, havia, geralmente, corrida de cavalos, e também festa popular como ocorreu, respectivamente, nos dias 11 e 12 de abril de 1909. A entrega dos prêmios foi no Kapps Hotel ( $L Z, 03.04 .1909$, p. 3). Em meados de abril de 1909, o jornal local publicou matéria sobre outra corrida de cavalo. Salientou a presença feminina e de autoridades oficiais, além da performance da banda musical dos marinheiros do navio imperial "Sperber" que animou o público. As próximas corridas seriam no feriado de Pentecostes ( $L Z, 17.04 .1909$, p. 5). Dessa vez, a animação musical ficou por conta da banda do navio imperial "Panther". O encerramento do evento foi um jantar festivo no Kapps Hotel (LZ, 05.06.1909, p. 5$6)$.

Também no salão do Kapps Hotel foi a entrega dos prêmios das corridas de cavalo de 25 de julho de 1909 que ocorreu no Campo dos Bôeres. A entrada foi restrita aos associados e convidados (LZ, 24.07.1909, p. 3). Em setembro houve nova entrega de prêmios das corridas promovidas pela sociedade local de corridas, seguida de um baile no Kapps Hotel ( $L Z, 18.09 .1909$, p. 10).

Corridas de cavalos em outras localidades como Keetmanshoop ou Swakopmund também eram anunciadas no jornal de Lüderitz. Senhores e damas se deslocavam para prestigiar esses eventos esportivos e sociais. Desse modo, algumas formas de sociabilidade dependiam de certa circulação interna de pessoas na colônia alemã do sudoeste africano. Na Baía de Lüderitz, as corridas de cavalo do mês de novembro de 1910 atraíram grande público, inclusive feminino, permitindo a todos "se maravilhar com a moda chique e as novidades da toilette das damas que ocupavam a 
tribuna" (LZ, 19.11.1910, p. 1-2).

No Campos dos Bôeres, outras práticas esportivas também eram realizadas, bem como festas para um grande público. No entanto, em meados de 1909, foi noticiado no jornal local a previsão de passar os trilhos do trem pelo campo esportivo. O assunto foi um dos temas de discussão na reunião mensal da associação de moradores, realizada no salão do Hotel Rösemann em meados de junho daquele ano (LZ, 19.06.1909, p. 2).

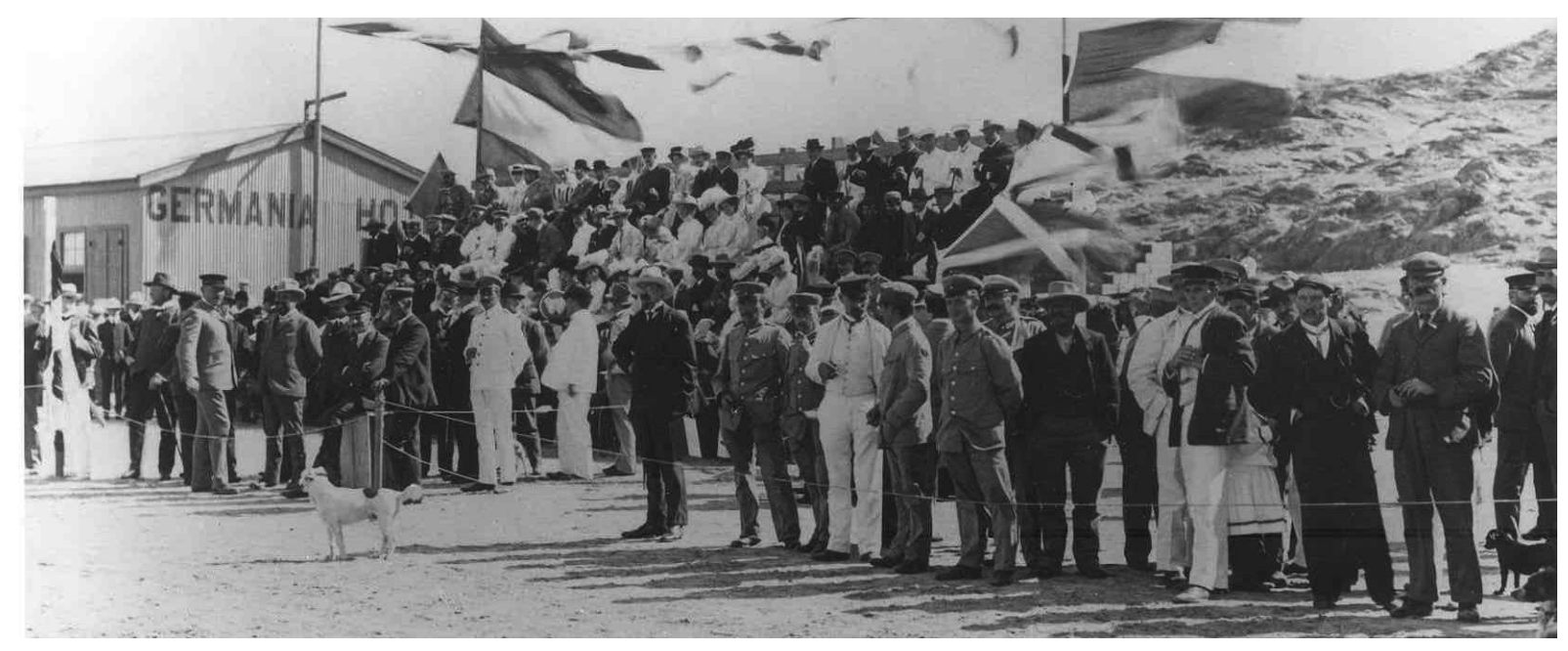

Figura 6 - Assistência durante uma corrida de cavalos no Campo dos Bôeres (Baía de Lüderitz). Na tribuna, tem-se a presença feminina. Ao fundo, vista parcial do pavilhão do Hotel Germania. National Archive of Namibia (Windhoek), Photo Nr. 00332.

As corridas de cavalos continuaram a ser realizadas no Campo dos Bôeres até o final de 1909 ( $L Z, 16.10 .1909$, p. 7). Em janeiro, as corridas de cavalos foram realizadas em outro lugar, segundo anúncios do jornal local ( $L Z, 15.01 .1910$, p. 3) o que permite inferir um novo espaço de sociabilidades. Em fevereiro de 1910, corridas de cavalo se realizaram no quadro das festividades do aniversário do imperador. $A$ sociedade de combatentes e a de corrida organizaram as festividades nos Altos de Malta, localidade próxima da cidade e que passou a acolher as corridas de cavalos e outras festas populares. Segundo o jornal local, africanos também participaram da Festa do Kaiser nos Altos de Malta, inclusive com música e jogos (LZ, 19.02.1910, p. 5).

Outras comemorações eram realizadas pela comunidade da Baía de Lüderitz. O jubileu dos 25 anos da fundação da cidade foi comemorado no Kapps Hotel (LZ, 11.09.1914, p. 2-3). Da confeitaria do senhor Deubler vieram as "delícias" elogiadas em nota no jornal local. Cabe lembrar que a confeitaria do senhor Deubler se localizava ao lado da casa comercial de Louis Worms. Este último era membro de 
várias associações locais e da comissão de algumas corridas de cavalo em 1909 e cujas reuniões e premiações ocorriam nos salões do Kapps Hotel. Por isso, as relações pessoais entre os hoteleiros Büttow e Bauer e os comerciantes Worms e Deubler podem esclarecer as escolhas dos lugares e dos serviços para certas práticas de sociabilidades como as comemorações do jubileu da cidade.

Entre as ocasiões esporádicas da vida social na Baía de Lüderitz podem ser destacadas ainda as apresentações de artistas vindos da Europa. Geralmente, essas apresentações ocorriam na sala de concerto do Kapps Hotel como, por exemplo, o concerto do trio russo Cherniavski ( $L Z, 09.10 .1909$, p. 2). O mesmo empresário dos irmãos russos, o senhor Llewellyn, foi responsável pela apresentação de outro ensemble na Konzerthaus do Kapps Hotel e cuja programação foi a ópera Fausto e a Cavalleria Rusticana, respectivamente na primeira e segunda noite (LZ, 13.11.1909, p. 3; LZ, 27.11.1909, p. 5).

Outras raras ocasiões eram as exposições de arte, notadamente pinturas a óleo e aquarelas de paisagens coloniais, como a do pintor bávaro Ernst Vollbehr (LZ, 05.03.1910:8). Também pintores locais como Paul Sackmann faziam exposições de aquarelas de paisagens e marinhas da Baía de Lüderitz (LZ, 09.07.1910, p. 2; LZ, 27.08.1910, p. 2). Algumas palestras eram realizadas nos salões dos hotéis como, para não passar de um exemplo, na sexta-feira à noite de 10 de junho de 1910, no Kapps Hotel, quando o Dr. Paul Rohrbach foi convidado pela filial local da Liga Feminina da Sociedade de Colonização Alemã para tratar sobre o passado, o presente e o devir do sudoeste africano. Essas atividades artísticas e culturais eram ocasiões para a prática de sociabilidades entre os anfitriões, convidados e o público local.

Dos feriados religiosos, Páscoa e Natal eram ocasiões para se encontrar em missas ou cultos, mas também nas atividades organizadas pelas associações ou sociedades locais. Desde sua fundação em 1910, o Clube Esportivo organizava "jogos olímpicos" durante a Páscoa. Aliás, o patrono do Clube Esportivo era o prefeito Kreplin (LZ, 19.03.1910, p. 9). Nota-se uma adequação do tempo profano dos esportes ao calendário religioso na colônia alemã do sudoeste africano. Mas se o tempo profano do esporte não era algo totalmente separado do tempo religioso naqueles confins da África, ao menos, o calendário esportivo favoreceu uma nova perspectiva em relação ao tempo de outrora. Como na Europa do final do século XIX, o esporte inaugurou um tempo separado da vida cotidiana, com ritmo (quase) autônomo e manifestações próprias; um tempo de ruptura com o mundo do trabalho; e, um tempo de atividades intensas, geralmente, concentradas num dia ou dois (VIGARELLO, 1995, p. 215).

Ao contrário das corridas de cavalos que exigiam uma maior organização 
devido, entre outros fatores, à sua popularidade e ao que elas representavam para a comunidade alemã do sudoeste africano, outros eventos esportivos ocorriam durante o ano. Lutas de box eram realizadas no Kapps Hotel e jogos de futebol e cricket eram organizados pelo Clube Esportivo ( $L Z, 19.03 .1910$, p. 9; LZ, 26.03.1910, p. 4). A prática dessas modalidades esportivas demonstram o quanto a situação portuária da pequena cidade favorecia o intercâmbio com a vizinha Colônia do Cabo e a influência de uma cultura esportiva inglesa e sul-africana e que se tornaria mais marcante após 1915.

No período natalino havia uma série de atividades organizadas pelas associações e também pelos hoteleiros ou donos de restaurantes. Assim que a última semana do ano era um período de intensa vida social na Baía de Lüderitz. Concertos, espetáculos, bailes e jantares não podiam faltar. No domingo de 25 de dezembro de 1910, houve um concerto natalino no Kapps Hotel ( $L Z, 24.12 .1910$, p. 4). Em 1911, o jornal local anunciou um sensacional programa natalino de cinema do Kapps. Realizaram-se ainda corridas de cavalo no último domingo daquele ano (LZ, 23.12.1911, p. 3). Também foram realizadas corridas de cavalo no primeiro dia de 1914 (LZ, 26.12.1913). Para dar mais alguns exemplos, a sociedade de teatro se apresentou no salão do Kapps Hotel na semana natalina de 1911 (LZ, 30.12.1911, p. 2) e a sociedade masculina de canto se apresentou no mesmo local no dia 26 de dezembro por três anos seguidos (LZ, 21.12.1912, p. 4; LZ, 26.12.1913, p. 4; LZ, 02.01.1914, p. 2), sendo a apresentação lírica sempre seguida de baile.

Esses exemplos todos comprovam a importância das associações locais para a vida social na Baía de Lüderitz durante o domínio colonial alemão. Como publicado em matéria do jornal local em ocasião ao sétimo aniversário da associação dos moradores, a comemoração realizada no Kapps Hotel foi uma justa homenagem "pela forma como a associação promovia e cuidava da sociabilidade entre seus membros e seus convidados" (LZ, 19.09.1913, p. 2).

\section{"Buquês sociais" na Baía de Lüderitz}

Depois de 1908, houve um aumento populacional na Baía de Lüderitz. Embora houvesse um bom número de trabalhadores no porto marítimo, os areais diamantinos concentraram boa parte da mão-de-obra africana. Homens Kru da Serra Leoa, Ovambo do sul de Angola, Cafres da África do Sul, entre outros, levavam uma vida segregada dos espaços sociais quase restritos exclusivamente aos alemães. Nos compounds de cada sociedade diamantina havia, provavelmente, momentos de distração dos trabalhadores. Conversas, jogos de azar e bebidas espirituosas faziam 
parte destes momentos conforme se pode inferir dos processos criminais da Baía de Lüderitz. ${ }^{10}$ Mas esse convívio social nos compounds e sob forte vigilância policial não se enquadra na categoria de sociabilidade, pois aquelas condições eram inadequadas para uma vida social intensa e espontânea.

Ao contrário dos trabalhadores negros ou mestiços, os trabalhadores brancos de origem europeia ou sul-africana tinham acesso a certos espaços sociais na Baía de Lüderitz. Mas as práticas de sociabilidade eram quase que um apanágio da elite local. Cabe ressaltar que a incipiente sociedade colonial na "África alemã" se estruturava sobre a rigidez que separava adventícios alemães e nativos africanos. A vida social nos espaços públicos era praticada por uma gente predominantemente branca.

Apesar da cor branca dos alemães, o "buquê social" que se formava nos salões dos hotéis, num café ou na tribuna de uma corrida de cavalos não era monocromático. Origem e posição social distintas davam um colorido, mesmo sem muito matiz, ao "buquê social" que espontaneamente se configurava nos espaços de sociabilidade na Baía de Lüderitz. ${ }^{11}$ Além disso, havia a clivagem regional. Se o dialeto podia acusar a origem natal de alguém, trejeitos ou maneiras de falar e de se comportar em lugares públicos, como cafés e salões, podiam revelar a origem social distinta daqueles que compartilhavam a vida social numa pequena cidade portuária do sudoeste africano. Assim, no seio da comunidade alemã da Baía de Lüderitz formavam-se em várias ocasiões, num salão de hotel ou num passeio a cavalo, diferentes "buquês sociais".

Embora as práticas de sociabilidade pudessem misturar numa só fragrância o conjunto variado de um "buquê social", alguns elementos raramente faziam parte dele. Afinal, os africanos eram excluídos dos espaços de sociabilidades. Sua presença era tolerada enquanto empregados domésticos, criados ou tendo outra função subalterna. Em fotografias ou notícias de algumas festividades ou eventos que faziam parte da vida social dos alemães, a presença africana era rara. Os poucos registros confirmam, invariavelmente, a posição doméstica e subalterna dos africanos.

\footnotetext{
${ }^{10}$ Strafprozess-Sachen. Inventar der AktendesKaiserlichenBezirksamtsLüderitzbucht (BLU) 1896/1915, v.2. National Archives of Namibia, Windhoek.

${ }^{11}$ Como já foi referido (nota de rodapé 4), o termo "buquê social" é uma figura de linguagem proustiana que faz alusão a um exercício de "sociologia prazerosa" que Swann gostava de fazer ao juntar pessoas socialmente distintas numa mesma ocasião.
} 


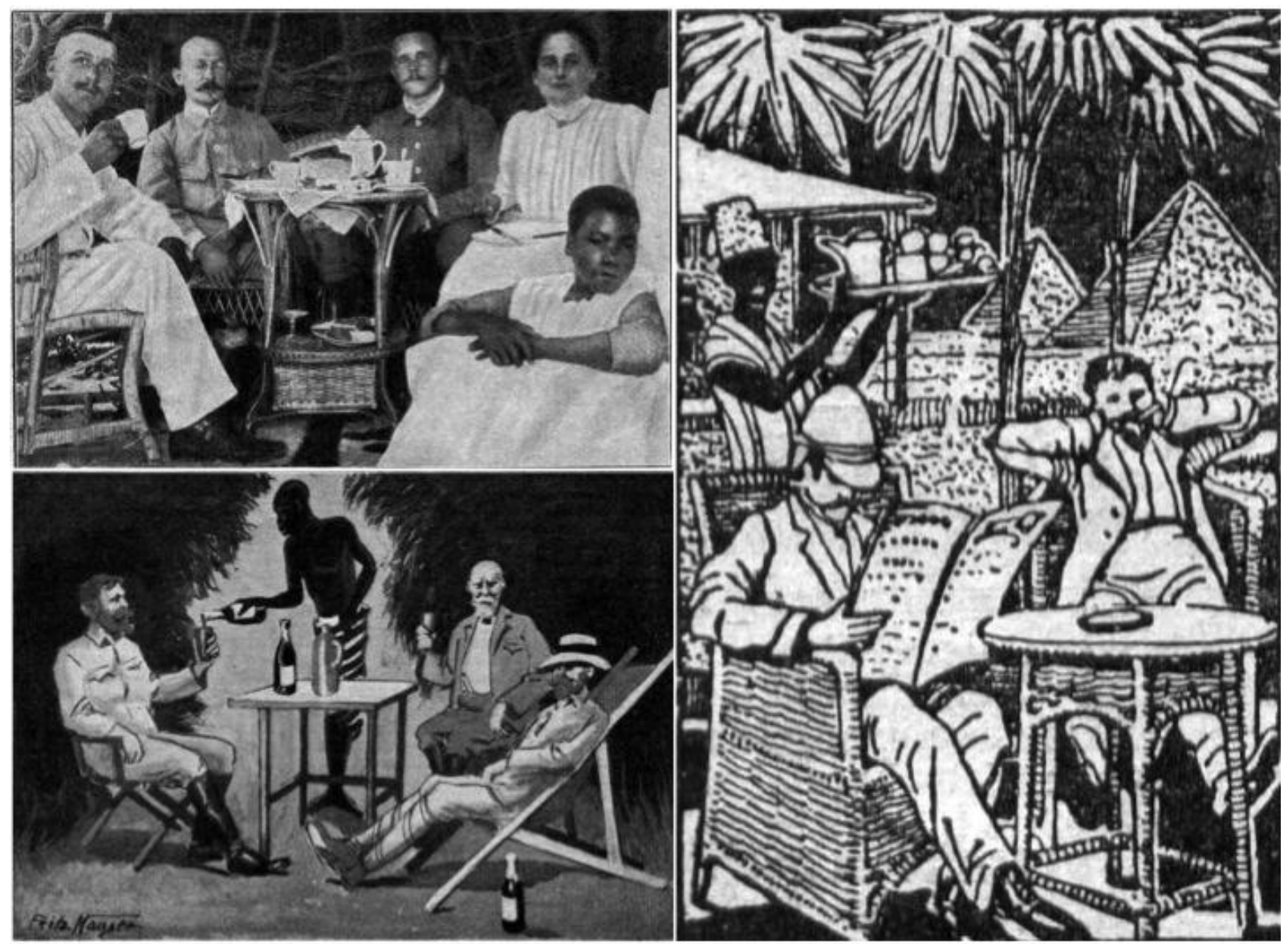

Figura 7 - Representações coloniais de cenas de convívio social com presença africana em situação servil: (1) Kolonie und Heimat in Wort und Bild, Nr. 14, Berlin, 25.12.1910, S.06; (2) Kolonie und Heimat in Wort und Bild, Nr. 24, Berlin, 05.03.1911, S.07; (3) Kolonie und Heimat in Wort und Bild, Nr. 26, Berlin, 19.03.1911, S.16

Poucas eram as ocasiões festivas compartilhadas por africanos e europeus. $\mathrm{Na}$ África colonial, alguns espaços de sociabilidade tiveram fronteiras mais porosas, especialmente para uma elite africana. Em datas comemorativas como o aniversário do Kaiser, régulos locais eram convidados para participar das festividades, etc. Algumas comemorações civis, militares e religiosas eram populares. Eventos esportivos como as corridas de cavalos também podiam contar com a participação de alguns africanos, embora com lugares rigidamente definidos pela hierarquia da sociedade colonial. Nas primeiras corridas de cavalo de Windhuk houve uma modalidade na qual os cavalos eram de propriedade de africanos. Na Baía de Lüderitz, os africanos só podiam participar das corridas de cavalos como jóqueis ou na modalidade de corridas de mulas.

Também para algumas exposições coloniais, representantes das elites locais eram convidados. Alguns filhos da elite africana foram até para a Alemanha. Para a primeira exposição colonial de Berlim em 1896, por exemplo, o jovem Friedrich Maharero esteve presente (ZELLER, 2002). Ele era filho de Samuel Maharero, um dos 
principais líderes herero durante a guerra colonial no sudoeste africano. ${ }^{12}$

Cabe lembrar que, durante o colonialismo alemão, houve um aumentou da circulação de africanos pela Alemanha. A presença africana em cidades alemãs foi, inclusive, tema de várias caricaturas da imprensa alemã. Uma dessas caricaturas, para ficar num exemplo, ironizava as preferências de uma elite africana acostumada com a vida social de Berlim e Munique (SIMPLICISSIMUS, Heft 10, 1909, p. 8).

Diferente das cidades alemãs como Berlim e Munique, na Baía de Lüderitz, as relações entre alemães e africanos não se enquadraram nos moldes da sociabilidade urbana, pois a sociabilidade pressupõe uma "espontaneidade", uma vontade de querer estar com os outros. Em suma, uma predisposição para a convivência. Ora, os espaços públicos reservados aos africanos naquela incipiente sociedade colonial demonstram o quanto as relações entre alemães e africanos nada tinham de espontâneas e o quanto era mínima a vontade de conviver socialmente uns com os outros.

\section{O fim da colônia alemã e as sociabilidades no post bellum}

Da ocupação sul-africana em 1914 até o Tratado de Versalhes, o destino da colônia alemã do sudoeste africano ficou indefinido. À União Sul-Africana foi delegado o comando da região pelo Conselho das Nações em 1920. Isso teve impacto nas práticas de sociabilidade na Baía de Lüderitz e outras localidades da ex-colônia alemã. Afinal, as associações reproduziam uma vida social germânica no sudoeste africano. Porém, os hoteleiros, as associações locais e a comunidade alemã continuaram suas atividades sociais. Para não passar de um exemplo, houve um concerto beneficente para crianças pobres na Alemanha, realizado no Salão do Kapps Hotel em 20 de fevereiro de 1920. Na programação, entre outras, músicas de Mendelssohn, Chopin, Schubert e Offenbach. (LZ, 17.02.1920, p. 2).

Em 1922, o tradicional Kapps Hotel anunciava boliche, bilhar, salas de cinema e teatro, e espaços apropriados para encontros, reuniões e festividades, além de outras atividades para a comunidade local e hóspedes eventuais. (LZ, 1.04.1922, p. 4). Em 1922, a Sociedade Ginástica já realizava seus encontros em ginásio próprio (3.04.1922, p. 2). Outros estabelecimentos surgiram. Paul Rümmler tinha um hotel com seu nome em 1922 (LZ 06.02.1922, p. 2). Nele foram realizadas reuniões dos bombeiros voluntários (LZ, 01.02.1922, p. 2), da sociedade de natação, fundada em

\footnotetext{
${ }^{12}$ A guerra colonial resultou no genocídio dos herero. A ordem de extermínio foi dada pelo alto comando militar das tropas alemãs. Na historiografia, a ordem de extermínio (Vernichtungsbefehl) do general Lothar von Trotha, de 2 de outubro de 1904, passou a ser a chave documental do genocídio. Calcula-se que cerca de 70 mil pessoas foram mortas entre os herero, ou seja, cerca de $80 \%$ da sua população à época. Em torno de 14 mil soldados alemães participaram da guerra colonial (CORREA, 2011, p. 88).
} 
1915, (LZ, 11.04.1922, p. 2) e da tradicional sociedade dos combatentes (LZ, 19.04.1922, p. 2). A sociedade de canto ainda se reunia no Kapps Hotel em 1922, onde também ocorreu a reunião anual dos membros do Tênis Clube (LZ, 22.04.1922, p. 6). No Europäischer Hof houve ainda uma série de reuniões de associações durante o ano de 1922. Evidentemente, havia novas práticas de sociabilidades, inclusive com a participação de britânicos e bôeres. Às vésperas do Natal de 1922, o Kapps Hotel foi local de uma noite dançante para a qual foi convidada toda a comunidade alemã e da União Sul-Africana. (LZ, 07.12.1922, p. 2)

Mas o ano de 1922 foi um marco na vida associativa na Baía de Lüderitz, pois se discutiu a fusão das sociedades alemães numa confederação (Gemeinbürgschaft) (LZ, 11.02.1922, p. 3). Tratava-se de uma política comunitária para centralização dos esforços para a manutenção de uma identidade étnica. Ao mesmo tempo, as formas e os espaços de sociabilidades no sudoeste africano se ajustavam ao modo de vida sulafricano.

\section{Considerações finais}

Quase 40 anos depois da bandeira do II Reich ter sido hasteada na Baía de Lüderitz, as práticas de sociabilidade tinham se desenvolvido, em grande parte, pela vida associativa dos alemães. A maioria das associações locais surgiu depois da guerra colonial no sudoeste africano (1904-1907) e seu desenvolvimento foi concomitante com aquele da economia local, baseada principalmente na exploração do diamante. Devido à mineração, a pequena cidade portuária da Baía de Lüderitz se tornou uma escala obrigatória na circulação de pessoas e mercadorias através da navegação marítima entre Swakopmund e a Colônia do Cabo. Com a presença constante de navios da frota imperial ou mercantes da linha Woermann ou de companhias de navegação inglesas ou sul-africanas, a vida social local teve sempre a participação de compatriotas e estrangeiros de passagem. Isso conferia às sociabilidades locais um diferencial. Porém, as sociabilidades atendiam mais interesses locais, principalmente dos residentes alemães. Apesar da participação esporádica de ingleses, bôeres e outros em algumas festividades, as sociabilidades serviram para cultivar o germanismo (Deutschtum) dos imigrantes alemães e seus descendentes.

As sociabilidades contribuíram para a coesão social de pessoas que tinham alguns interesses em comum e também para a reinvenção de um German way of life num contexto colonial. Se as sociabilidades favoreceram a reconstrução de uma identidade alemã, elas também serviram para excluir aqueles que não tinham acesso aos espaços onde se praticava a vida associativa, como os salões de hotéis. Os 
principais hotéis na Baía de Lüderitz foram o Europäischer Hof, o Rösemann e o Kapps, onde reuniões de associações (de canto, de teatro, de ginástica, etc.) ocorriam com regular frequência. Além disso, os hoteleiros promoviam uma série de atrações culturais (concertos musicais, programa de variedades ou de cabaré, cinematógrafo, etc.) e sociais (bailes, jantares, festas, etc.). Para isso, contavam os hoteleiros com a participação das associações locais e a adesão do público. Pela dinâmica e intensidade das práticas de sociabilidades locais, pode-se inferir que, em vários dias da semana, no salão de um ou outro hotel, exalavam fragrâncias distintas pela composição dos "buquês sociais" que se formavam.

Como os salões dos hotéis, a tribuna do Campo dos Bôeres foi outro espaço de sociabilidades para homens e mulheres, adultos e crianças. Evidentemente, dela estavam excluídos os africanos, assim como dos salões dos hotéis, da praia balneária e de tantos outros espaços de sociabilidade. As exceções eram raras. Em geral, os africanos tinham uma participação marginal e subalterna na vida social da pequena cidade portuária da Baía de Lüderitz. No Campo dos Bôeres, as práticas esportivas como turfe, tênis ou atletismo reservavam a eles o lugar de jóqueis, gandulas e carregadores, além de espectadores distantes, detrás dos alambrados.

Com base em matérias e anúncios de jornais da imprensa colonial em língua alemã, pode-se inferir que a vida social na Baía de Lüderitz foi organizada mormente pelas associações locais. As práticas de sociabilidade tiveram nos salões dos hotéis seus espaços de maior ocorrência e nos hoteleiros seus principais anfitriões. Mas a vida associativa no sudoeste africano teve que se ajustar a uma nova ordem política. Apesar da capitulação das tropas alemãs em 9 de julho de 1915, algumas associações locais lograram, todavia, manter suas atividades sociais durante a tutela sul-africana.

\section{Fontes}

DOAZ Deutsch-Ostafrikanische Zeitung

Dar-es-Salaam (1899-1916)

Bibliothek der Goethe Universität, Frankfurt am Main

Digitale Dokumente

DSWAZ Deutsche Südwestafrikanische Zeitung

Swakopmund (1901-1914)

African Newspapers Database

Digitale Dokumente 
KuH Kolonie und Heimat in Wort und Bild

Berlin (1909-1911)

Unabhängige koloniale Zeitschrift des Frauenbundes

der deutschen Kolonialgesellschaft

Digitale Dokumente

LZ

Lüderitzbuchter Zeitung

Lüderitzbucht (1909-1922)

African Newspapers Database

Digitale Dokumente

SZ Swakopmunder Zeitung

Swakopmund (1911-1912)

African Newspapers Database

Digitale Dokumente

WA Windhoeker Anzeiger

Windhuk (1898-1901)

African Newspapers Database

Digitale Dokumente

\section{Referências}

ADRESSBUCH für Stadt und Bezirk Lüderitzbucht (1914). Lüderitzbucht: R. Geschke.

AGULHON, Maurice. La sociabilité méridionale, confréries et associations dans la vie collective en Provence orientale à la fin du XVIIIe siècle. Aix-en-Provence: Publications des Annales de la Faculté des Lettres (Série Travaux et Mémoires, n' XXXVI), 1966.

AGULHON, Maurice. El círculo burgués. La sociabilidad en Francia, 1810-1848. Buenos Aires: Siglo Veintiuno Editores, 2009.

ARENDT, Hannah. Origens do Totalitarismo. anti-semitismo, imperialismo, totalitarismo. São Paulo: Companhia das Letras, 1989.

BRESCIANI, Maria Stella. Uma viagem política pelos domínios das fições literárias (prefácio). In: BREHPOHL, Marion. Imaginação Literária e Política. Os alemães e o 
imperialismo 1880/1945. Uberlândia: EDUFU, 2010.

BROCKMANN, Clara. Briefe eines deutschen Mädchens aus Südwest, Berlin: Ernst Siegfried Mittler und Sohn, 1912.

CHALINE, J.-P. Sociabilité et érudition. Les sociétés savantes en France XIXe-XXe siècles. Paris: Éditions du CTHS, 1995.

CORREA, Sílvio M. de S.. História, memória e comemorações: em torno do genocídio e do passado colonial no sudoeste africano. Revista Brasileira de História. São Paulo, v. 31, no 61, p. 85-103. 2011.

CORREA, Sílvio M. de S. Colonialismo, germanismo e ginástica no sudoeste africano. Recorde: Revista de História do Esporte, v. 5, p. 134-156, 2012.

FORSÉ, Michel. Quelques éléments sur la sociabilité (thèse de doctorat de troisième cycle en sociologie). Paris: IEP, 1980.

FRANÇOIS, Etienne. Sociabilité et société bourgeoise en France, en Allemagne et en Suisse (1750-1850). Paris: Editions Recherche sur les Civilisations (ERC), 1987.

FUMAROLI, Marc et al. Élites et sociabilité en France. Paris: Perin, 2003.

GUTTON, Jean-Pierre. La sociabilité villageoise dans l'ancienne France. Solidarités et voisinages du XVIe au XVIIIe siècle. Paris: Hachette, 1979.

HARDTWIG, Wolfgang. Strukturmerkmale und Entwicklungstendenzen des Vereinswesens in Deutschland 1789-1848. Historische Zeitschrift. Beihefte, Vol. 9, p. 11-50, 1984.

IMHOF, U.. Das gesellige Jahrhundert. Gesellschaft und Gesellschaften im Zeitalter der Aufklärung. München, 1982.

KALE, Steven D.. French Salons, High Society, and Political Sociability from the Old Regime to the Revolution of 1848. Baltimore: JHU Press, 1994.

LILTI, Antoine. Le monde des salons: sociabilité et mondanité à Paris au XVIIIe siècle. Paris: Fayard, 2005.

MAYER, Michael. Der Verein in der Spätmoderne. Eine evolutionstheoretische Analyse. Konstanz: Universität Konstanz, 2006.

NATHAUS, Klaus. Organisierte Geselligkeit. Deutsche und britische Vereine im 19. und 20. Jahrhundert. Göttingen: Vandenhoeck \& Ruprecht, 2009.

PROUST, Marcel. À I'ombre de jeunes filles en fleurs. Paris: Gallimard, 1988.

SAID, Edward. Cultura e imperialismo. São Paulo: Companhia das Letras, 2011.

VIGARELLO, Georges. Le temps du sport. In: CORBIN, Alain et al. L'avènement des loisirs, 1850-1960. Paris: Flammarion, 1995.

WASSINK, Jörg. Auf den Spuren des deutschen Völkermordes. In: Südwestafrika. 
München: Martin Meidenbauer Verlag, 2004.

WARMBOLD, Joachim. "Ein Stückchen neu Deutsche Erde..." Deutsche Kolonialliteratur, Aspekte ihrer Geschichte, Eigenart und Wirkung, dargestellt am Beispiel Afrikas. Frankfurt: Haag und Herchen Verlag, 1982.

WEBER, EUGEN. França Fin-de-Siècle. São Paulo: Companhia das Letras, 1988.

WESSELING, Henri. Les empires coloniaux européens 1815-1819. Paris: Gallimard, 2004.

ZELLER, Joachim. Friedrich Maharero - Ein Herero in Berlin. In: Ulrich van der Heyden; Joachim Zeller (Hrg.). Kolonialmetropole Berlin. Eine Spurensuche. Berlin, 2002. 